\title{
KUALITAS PERNIKAHAN DAN KESEJAHTERAAN KELUARGA MENENTUKAN KUALITAS LINGKUNGAN PENGASUHAN ANAK PADA PASANGAN YANG MENIKAH USIA MUDA
}

\author{
Fatma Putri Sekaring Tyas ${ }^{\left.1^{*}\right)}$, Tin Herawati ${ }^{1}$ \\ ${ }^{1}$ Departemen IImu Keluarga dan Konsumen, Fakultas Ekologi Manusia, Institut Pertanian Bogor, Bogor 16680, \\ Indonesia \\ *)E-mail: putrityas27@gmail.com
}

\begin{abstract}
Abstrak
Penelitian ini bertujuan untuk menganalisis pengaruh karakteristik keluarga, kualitas pernikahan, dan kesejahteraan keluarga terhadap kualitas lingkungan pengasuhan pada pasangan yang menikah di usia muda. Pemilihan lokasi dilakukan secara purposive yaitu di dua desa di Kecamatan Ciampea, Kabupaten Bogor, Provinsi Jawa Barat. Contoh berjumlah 70 keluarga yang dipilih secara purposif dengan pertimbangan suami dan istri menikah di usia muda dan mempunyai anak usia 0-6 tahun. Data dikumpulkan melalui wawancara dan observasi, serta dianalisis dengan statistik deskriptif dan uji regresi linear berganda. Hasil analisis menemukan mayoritas kualitas pernikahan yang terdiri atas kebahagian dan kepuasan pernikahan termasuk dalam kategori sedang. Kesejahteraan objektif keluarga termasuk kategori sejahtera dan kesejahteraan subjektif terkategori sedang. Mayoritas keluarga mempunyai kualitas lingkungan pengasuhan pada anak usia 0-36 bulan termasuk dalam kategori rendah dan kualitas lingkungan pengasuhan pada anak usia 37-72 bulan termasuk dalam kategori sedang. Hasil analisis regresi menemukan kualitas lingkungan pengasuhan anak dipengaruhi secara signifikan dan positif oleh lama menikah, usia menikah istri, kualitas pernikahan, dan kesejahteraan subjektif.
\end{abstract}

Kata kunci: kesejahteraan objektif, kesejahteraan subjektif, kualitas pernikahan, lingkungan pengasuhan, pasangan menikah usia muda

\section{Marriage Quality and Family Well-Being Determine Parental Environment of Early Marriages}

\begin{abstract}
This study aimed to analyze the influence of family characteristics, quality of marriage, and family well-being toward the quality of parental environment among early marriage families. Research is done in two villages in Ciampea District, Bogor Regency, West Java Province. Samples consist of 70 families selected purposively with consideration of husband and wife married at a young age and have children aged 0-6 years old. Data were collected through interviews and observations and analyzed with descriptive statistics and multiple linear regressions. The analysis found that majority family had marriage quality in the medium category. Meanwhile, a majority of the family were categorized as prosperous family based on objective well-being indicator and had subjective family well-being in the medium category. This research also found that the majority of quality of parental environmental for children aged 0-36 months was categorized as low environment and children aged 3772 months in the medium category. Marriage age, the marriageable age of wife, marriage quality, and subjective well-being significant and positive influenced toward the quality of parenting environment.
\end{abstract}

Keywords: early marriage, marriage quality, objective well-being, parental environment, subjective well-being

\section{PENDAHULUAN}

Pernikahan merupakan gerbang pertama yang biasanya dilewati oleh periode dewasa muda untuk memulai kehidupan. Pernikahan di usia muda adalah pernikahan yang dilakukan oleh pasangan ataupun salah satu pasangannya masih dikategorikan remaja yang berusia kurang dari 19 tahun (WHO, 2006) atau pernikahan yang dilakukan sebelum usia 20 tahun (BKKBN, 2012). Menurut BKKBN (2012),
Indonesia termasuk negara dengan persentase pernikahan usia muda yang tinggi di dunia (rangking 37). Beberapa alasan yang menyebabkan terjadinya pernikahan di usia muda adalah status sosial dan ekonomi yang rendah, tingkat pendidikan yang rendah, adanya budaya nikah muda, pernikahan yang dipaksa, dan seks bebas (BKKBN, 2012). Menurut Paul, Joseph, dan ljeoma (2013), kemiskinan merupakan penyebab utama pernikahan usia muda. Dengan menikahkan 
anaknya maka beban ekonomi dan tanggungan orang tua semakin berkurang. Padahal, pasangan yang menikah di usia muda rentan dengan masalah, salah satunya adalah permasalahan ekonomi.

Menurut Rahman dan Nasrin (2012), permasalahan utama dalam kehidupan pernikahan di usia muda adalah pendidikan dan pendapatan bulanan yang rendah. Selain itu, perempuan yang menikah muda harus menghadapi banyak permasalahan lingkungan dan sosial sehingga mereka harus mampu beradaptasi untuk mengatasi stres dan tekanan yang muncul dalam kehidupan keluarganya (Ahmed et al., 2013; Shabbir dan Nisar, 2015). Menurut BKKBN (2012), dampak yang terjadi akibat menikah di usia muda diantaranya adalah kasus drop out sekolah tinggi, terjadinya kekerasan dalam rumah tangga (KDRT), peluang kematian ibu tinggi, lama sekolah rendah, dan hak kesehatan reproduksi rendah.

Permasalahan ekonomi yang terjadi dalam kehidupan pernikahan di usia muda dapat memengaruhi kualitas pernikahan. Hasil penelitian Sunarti et al. (2005) menunjukkan bahwa tekanan ekonomi keluarga berkaitan erat dengan kualitas pernikahan. Keluarga akan memperoleh kebahagiaan apabila mempunyai uang yang cukup (Tati, 2004). Hal ini dapat terjadi karena keluarga membutuhkan sumber daya untuk memenuhi kebutuhannya. Conger, Conger, dan Martin (2010) juga menambahkan bahwa kelas sosial atau status sosial ekonomi keluarga akan berkaitan dengan kepuasan dan stabilitas dalam pernikahan. Permasalahan ekonomi dapat merenggangkan hubungan dalam keluarga. Hal ini dapat terjadi karena pendidikan dan pendapatan yang rendah merupakan faktor yang menyebabkan stres dan kerenggangan dalam suatu hubungan (Schramm, 2007).

Selain faktor ekonomi, tingkat pendidikan yang rendah menjadi juga menjadi faktor yang menyebabkan terjadinya pernikahan di usia muda. Pendidikan yang rendah berdampak pada kesulitan dalam mencari pekerjaan dan pada akhirnya memengaruhi jumlah pendapatan yang diterima. Pendapatan yang rendah berdampak pada kesejahteraan keluarga baik secara objektif maupun subjektif. Iskandar et al. (2007) menyatakan keluarga yang mempunyai pendapatan tinggi memiliki peluang lebih besar untuk sejahtera dibandingkan dengan keluarga dengan pendapatan rendah. Helliwell dan Putnam (2004) juga menyatakan bahwa kesejahteraan subjektif secara tidak langsung dipengaruhi oleh tingkat pendidikan individu. Sementara itu, Allendorf dan Ghimire (2012) menemukan bahwa pendidikan mempunyai hubungan yang kuat dan konsisten dengan kualitas pernikahan.

Pernikahan di usia muda juga berdampak pada ketidaksiapan keluarga dalam mengemban tugas untuk mengasuh anak. Menurut Tsania (2014), ibu yang menikah muda belum memiliki kesiapan dalam menjalankan fungsi pengasuhan. Keterbatasan informasi dan pengetahuan, rendahnya sosialisasi serta kematangan usia diduga menjadi penyebab ketidaksiapan ibu muda dalam mengasuh anak. padahal fungsi pengasuhan pada akhirnya akan berdampak pada kualitas anak.

Beberapa penelitian menemukan bahwa adanya hubungan antara kualitas pernikahan dengan lingkungan pengasuhan anak. Rizkillah, Sunarti, dan Herawati (2015) menunjukkan bahwa kualitas lingkungan pengasuhan dipengaruhi salah satunya adalah kualitas pernikahan. Lai (2011) juga menemukan bahwa kualitas pernikahan dari pasangan suami dan istri dan kualitas lingkungan keluarga merupakan faktor yang akan menentukan perilaku anak. Selanjutnya Rizkillah (2014) juga menemukan bahwa kualitas lingkungan pengasuhan juga dipengaruhi oleh kualitas pernikahan, pendidikan istri, dan besar keluarga. Bahkan Puspitawati dan Setioningsih (2011) menemukan bahwa interaksi antara ayah dan anak akan berpengaruh positif terhadap kualitas pernikahan. Kersh et al. (2006) juga menyatakan bahwa salah satu faktor yang memengaruhi kualitas pernikahan dari pasangan suami dan istri adalah karakteristik anak dan dukungan sosial.

Mengingat berbagai permasalahan yang dihadapi keluarga dengan pernikahan usia muda dan beberapa temuan dari penelitian terdahulu maka penelitian ini bertujuan untuk menganalisis kualitas pernikahan, kesejahteraan keluarga, dan kualitas lingkungan pengasuhan pada pasangan yang menikah di usia muda. Selain itu, penelitian ini bertujuan untuk menganalisis pengaruh karakteristik keluarga, kualitas pernikahan, dan kesejahteraan keluarga terhadap kualitas lingkungan pengasuhan pada pasangan yang menikah di usia muda.

\section{METODE}

Penelitian ini merupakan bagian dari penelitian payung yang berjudul "Tekanan Ekonomi, Kualitas Pernikahan, Ketahanan dan Kesejahteraan Keluarga, serta Lingkungan 
Pengasuhan pada Keluarga Menikah Usia Muda". Penelitian ini menggunakan desain cross sectional. Lokasi penelitian dipilih secara purposive yaitu di dua desa di Kecamatan Ciampea, Kabupaten Bogor, Provinsi Jawa Barat.

Keluarga yang dilibatkan dalam penelitian ini dipilih secara purposive yaitu keluarga yang menikah di usia muda menurut BKKBN, yaitu usia suami dan istri saat menikah adalah di bawah 25 tahun dan 20 tahun serta memiliki anak usia 0-6 tahun. Penelitian ini melibatkan 70 keluarga, dengan respondennya adalah istri.

Data primer yang dikumpulkan dalam penelitian ini adalah karakteristik keluarga, kualitas pernikahan, kesejahteraan keluarga, dan kualitas lingkungan pengasuhan. Data karakteristik keluarga, kualitas pernikahan, dan kesejahteraan keluarga dikumpulkan dengan cara wawancara sedangkan data kualitas lingkungan pengasuhan dikumpulkan dengan cara wawancara dan observasi.

Karakteristik keluarga terdiri atas usia suamiistri, lama menikah, besar keluarga, lama pendidikan suami-istri, pekerjaan suami-istri, dan pendapatan keluarga per kapita per bulan. Kualitas pernikahan terdiri atas dua dimensi yaitu dimensi kebahagiaan dan dimensi kepuasaan. Instrumen yang digunakan untuk mengukur kualitas pernikahan adalah instrumen yang dikembangkan oleh Sunarti et al. (2005) berdasarkan Conger et al. (1990). Instrumen ini terdiri atas 40 pertanyaan dengan pilihan jawaban "ya" dan "tidak". Instrumen yang digunakan telah reliabel dengan nilai Cronbach's alpha sebesar 0,843.

Kesejahteraan keluarga diukur secara objektif dan subjektif. Kesejahteraan objektif diukur dengan menggunakan 14 indikator keluarga miskin dari Badan Pusat Statistik (BPS). Indikator tersebut terdiri atas luas bangunan, jenis lantai, jenis dinding, fasilitas buang air besar, sumber air minum, sumber penerangan, jenis bahan bakar untuk memasak, frekuensi membeli daging, ayam dan susu dalam seminggu, frekuensi makan dalam sehari, jumlah pakaian baru yang dibeli dalam setahun, akses ke puskesmas/poliklinik, akses ke lapangan pekerjaan, pendidikan terakhir kepala rumah tangga, dan kepemilikan beberapa aset. Pilihan jawaban untuk setiap indikator adalah "ya" dan "tidak". Selanjutnya, kesejahteraan subjektif menggunakan kuesioner yang disusun oleh Puspitawati (2012). Instrumen ini mengukur kesejahteraan keluarga yang dilihat dari dimensi fisik-ekonomi, sosial, dan psikologis. Instrumen kesejahteraan subjektif terdiri atas 27 pertanyaan dengan pilihan jawaban "tidak puas", "cukup puas", dan "puas". Instrumen kesejahteraan subjektif telah reliabel dengan nilai Cronbach's alpha sebesar 0,943.

Kualitas lingkungan pengasuhan diukur dengan skala Home Observation for Measurement of the Environment (HOME) Inventory (Caldwell \& Bradley, 1984). Instrumen yang digunakan adalah Infant/ Toddler HOME (IT HOME) dan Early Childhood HOME (EC HOME). Skala IT HOME terdiri atas enam subskala yaitu sikap tanggap (responsivity), penerimaan (acceptance), pengorganisasian lingkungan anak (organization), ketersediaan media pembelajaran (learning materials), keterlibatan (involvement), dan variasi stimulasi (variety). Skala IT HOME terdiri atas 45 indikator dengan dua pilihan jawaban yaitu ya (skor 1) dan tidak (skor 0). Instrumen HOME telah reliabel dengan nilai Cronbach's alpha sebesar 0,944. Selanjutnya, EC HOME terdiri atas ketersediaan bahan ajar (learning materials); stimulasi bahasa (language stimulation); lingkungan fisik (physical environment); sikap tanggap (responsivity); stimulasi akademik (academic stimulation); modeling (modeling); variasi stimulasi (variety); dan penerimaan (acceptance). Skala EC HOME terdiri atas 55 indikator dengan dua pilihan jawaban yaitu ya (skor 1) dan tidak (skor 0). Instrumen HOME telah reliabel dengan nilai Cronbach's alpha sebesar 0,989. Skor kualitas lingkungan pengasuhan yang diperoleh dijumlahkan dan dikategorikan menjadi tiga kategori yaitu rendah, sedang, dan tinggi.

Data yang diperoleh diolah dianalisis dengan menggunakan statistik deskriptif dan uji regresi linear berganda. Statistik deskriptif digunakan untuk menghitung frekuensi distribusi, nilai minimum, nilai maksimum, nilai rata-rata, dan standar deviasi. Uji regresi linear berganda dilakukan untuk menganalisis pengaruh karakteristik keluarga, kualitas pernikahan, dan kesejahteraan keluarga terhadap kualitas lingkungan pengasuhan.

\section{HASIL}

\section{Karakteristik Keluarga}

Usia miminal menikah istri pada penelitian ini adalah 13 tahun dan usia menikah suami 16 tahun. Rata-rata usia suami ketika menikah adalah 22,1 tahun dan rata-rata ketika istri menikah adalah 17,3 tahun. Tingkat pendidikan yang telah dicapai lebih dari setengah $(60,0 \%)$ istri adalah tamat SD. Lama pendidikan yang 
ditempuh istri berkisar antara 3 sampai 12 tahun. Persentase tingkat pendidikan yang telah dicapai hampir setengah $(44,3 \%)$ suami adalah tamat SD. Lama pendidikan yang ditempuh suami berkisar 3 sampai 16 tahun. Rata-rata pendidikan istri dan suami adalah berjenjang SMP. Hasil penelitian menunjukkan tingkat pendidikan masih tergolong rendah dan belum menempuh pendidikan lebih dari sembilan tahun.

Hasil penelitian menunjukkan lebih dari setengah $(55,7 \%)$ suami mempunyai pekerjaan sebagai buruh dan jenis pekerjaan lainnya adalah wiraswasta, swasta, guru, dan penjahit. Sebanyak 81,4 persen istri menjadi ibu rumah tangga dan lainnya bekerja sebagai wiraswasta, buruh, dan penjahit. Besar keluarga contoh antara 3 sampai 9 orang dengan rata-rata berjumlah anggota keluarga 4 orang. Sementara itu, proporsi terbesar $(75,7 \%)$ keluarga termasuk dalam keluarga kecil. Pendapatan keluarga per kapita per bulan berkisar antara Rp75.000,00 hingga Rp2.500.000,00 dan rata-rata sebesar Rp594.696,00.

Penelitian ini menemukan bahwa lebih dari setengah $(52,9 \%)$ keluarga mempunyai anak berusia 37 sampai 72 bulan dan sisanya $(47,1 \%)$ berusia 0 sampai 36 bulan. Lama menikah pasangan suami istri berkisar 1 sampai 30 tahun dengan rata-rata lama menikah 11 tahun. Sebanyak 70,0 persen responden lama pernikahannya kurang dari 15 tahun dan sisanya 30,0 persen menikah lebih dari 15 tahun.

\section{Kualitas Pernikahan}

Kualitas pernikahan pada penelitian ini diukur dari dua dimensi, yaitu kebahagiaan pernikahan dan kepuasan pernikahan. Kebahagiaan pernikahan dilihat dari aspek ekonomi, komunikasi dengan keluarga pasangan, pengasuhan anak, kepribadian pasangan, komitmen pernikahan, dan hubungan intim. Pada aspek ekonomi, hasil penelitian menunjukkan mayoritas istri menyatakan kurang bahagia dan selalu berdebat dengan suami dalam hal alokasi uang membeli makan $(72,9 \%)$, alokasi uang untuk membeli pakaian $(71,4 \%)$, alokasi uang untuk pendidikan anak $(61,4 \%)$, alokasi uang untuk pengobatan $(57,1 \%)$, dan alokasi uang untuk merawat rumah $(55,7 \%)$.

Pada aspek komunikasi dengan keluarga pasangan, lebih dari setengah istri merasa bahagia dalam hal dianggap keluarga pasangan $(67,5 \%)$, tidak merasa direndahkan oleh mertua dan ipar (70,0\%), tidak kesulitan menganggap keluarga pasangan seperti keluarga sendiri $(67,5 \%)$, dan mudah berkomunikasi dengan pasangan (70,0\%).

Pada aspek pengasuhan anak, hasil penelitian menunjukkan bahwa mayoritas istri kurang bahagia dalam pengasuhan anak seperti sering bertengkar dengan suami mengenai anak $(75,7 \%)$, sering konflik dengan suami dalam mendidik anak $(70,0 \%)$, sering konflik dengan suami dalam mendisiplinkan anak (81,4\%), sering menemui hambatan dengan suami dalam mengasuh anak (65,7\%). Pada aspek kepribadian pasangan, proporsi terbesar istri kurang merasa bahagia dengan sikap pasangan yang tidak disukai $(68,6 \%)$, sifat pasangan yang tidak disukai $(68,6 \%)$, dan perilaku pasangan yang tidak disukai $(68,6 \%)$. Selain itu, kurang dari tiga perempat suami selalu memuji kemampuan istrinya $(74,3 \%)$.

Pada aspek komitmen pernikahan, mayoritas istri selalu menjaga komitmen pernikahan dengan suami $(81,4 \%)$, tetapi mayoritas istri juga merasa suami selingkuh $(52,9 \%)$. Pada aspek hubungan intim, lebih dari tiga perempat istri merasa terpaksa melakukan hubungan seks jika ada masalah dengan suami $(77,1 \%)$. Secara umum, kualitas pernikahan dalam aspek kebahagiaan pernikahan pada keluarga yang menikah di usia muda yang dipersepsikan istri termasuk dalam kategori sedang $(41,4 \%)$ (Tabel 1).

Sementara itu, dimensi kepuasan pernikahan juga dilihat dari aspek ekonomi, pengasuhan anak, serta cinta dan hubungan intim. Pada aspek keterbukaan dan aktivitas ekonomi, proporsi terbesar istri merasa kurang puas dalam hal sering konflik karena hanya satu sumber penghasilan keluarga $(52,9 \%)$, istri juga sering tidak puas dengan yang dimiliki sekarang $(61,4 \%)$, istri merasa kesal dengan kegagalan suami $(52,9)$, istri juga sering berbeda pendapat mengenai uang dengan suami $(70,0 \%)$, merasa terganggu dengan campur tangan orang lain dalam mencukupi keuangan keluarga $(55,7 \%)$.

Tabel 1 Sebaran keluarga berdasarkan kategori kualitas pernikahan (\%)

\begin{tabular}{lccc}
\hline Kategori & $\begin{array}{c}\text { Kebahagiaan } \\
\text { Pernikahan }\end{array}$ & $\begin{array}{c}\text { Kepuasan } \\
\text { Pernikahan }\end{array}$ & $\begin{array}{c}\text { Kualitas } \\
\text { Pernikahan }\end{array}$ \\
\hline Rendah & 37,1 & 4,3 & 18,6 \\
Sedang & 41,4 & 67,1 & 58,6 \\
Tinggi & 21,4 & 28,6 & 22,8 \\
\hline Total & 100,0 & 100,0 & 100,0 \\
\hline
\end{tabular}


Hasil analisis juga menemukan mayoritas istri telah merasa puas dengan pekerjaan suami $(74,3 \%)$, prestasi kerja suami $(64,3 \%)$, setuju dengan cara mengatur uang $(58,6 \%)$ dan terbuka dengan cara mengatur uang $(61,4 \%)$, istri juga tidak merasa terganggu dengan suami yang mengatur keuangan keluarga $(61,4 \%)$, dan tidak merasa terganggu jika keluarga besar meminta bantuan (54,3\%).

Dalam hal pengasuhan, istri kurang puas karena tidak ada pembagian tanggung jawab membesarkan anak (71,4\%), namun dalam suami dan istri jarang bertengkar dalam menentukan pendidikan anak $(54,3 \%)$. Pada aspek cinta dan hubungan intim, mayoritas istri merasa puas dengan suami yang mencintainya $(95,7 \%)$, suami memperlakukan seperti yang diinginkan $(80,0 \%)$, mempunyai waktu bersama dengan suami (82,9\%), senang mengungkapkan kepuasan seks $(78,6 \%)$, selalu musyawarah dalam menentukkan keputusan $(82,9 \%)$, istri merasa hubungan seksualitasnya indah dan menyenangkan $(54,3 \%)$. Namun, penelitian ini juga menemukan bahwa mayoritas istri kurang puas dengan tidak saling terbuka masalah seks $(55,7 \%)$. Secara umum, kepuasan pernikahan keluarga yang menikah di usia muda termasuk dalam kategori sedang $(67,1 \%)$.

Hasil yang tersaji pada Tabel 1 menunjukkan bahwa hanya ditemukan 1 dari 5 keluarga yang menikah usia muda terkatori tinggi, baik pada dimensi kebahagiaan pernikahan, kepuasan pernikahan, maupun kualitas pernikahan secara total. Sementara itu, nilai maksimum menunjukkan bahwa pada dimensi kebahagiaan pernikahan, terdapat keluarga yang menilai semua pernyataan dengan tidak bahagia (nilai minimum dimensi kebahagiaan yang dicapai keluarga responden adalah 0). Namun ada juga keluarga yang mengisi semua pernyataan pada dimensi kebahagiaan dengan bahagia semuanya dan semua pernyataan pada dimensi kepuasan dengan puas semuanya. Sementara itu berdasarkan nilai rata-rata dan standar deviasi, hasil penelitian menemukan bahwa dimensi kebahagiaan pernikahan $(44,3 \pm 25,2)$ mempunyai capaian terendah dibandingkan dimensi kepuasan pernikahan $(59,1 \pm 18,2)$ maupun kualitas pernikahan total $(59,7 \pm 19,9)$

\section{Kesejahteraan Keluarga}

Pada penelitian ini, kesejahteraan diukur secara objektif dan subjektif. Hasil pengukuran kesejahteraan keluarga secara objektif menunjukkan bahwa seluruh keluarga $(100,0 \%)$ berada dalam kategori keluarga sejahtera (Tabel 2). Menurut BPS (2000) semakin baik kondisi dan kualitas rumah yang ditempati menunjukkan semakin baik keadaan aset ekonomi rumah tangga tersebut. Walaupun terkategori sejahtera tetapi istri masih merasakan kurang dikarenakan keadaan rumahnya masih sempit dan tidak memiliki aset yang dapat dijual.

Hasil pengukuran kesejahteraan keluarga secara subjektif menunjukkan mayoritas istri $(77,1 \%)$ merasa kesejahteraan subjektif dalam kategori sedang (Tabel 2). Penyebab kesejahteraan subjektif termasuk kategori sedang adalah banyak istri yang kurang puas dengan keuangan keluarga, kebutuhan makanan keluarga, kepemilikan aset, keterlibatan keluarga dalam kegiatan sosial, pendidikan anggota keluarga, penghasilan suami, dan belum tercapai tujuan keluarga. Selanjutnya terdapat kurang dari sepuluh persen $(8,6 \%)$ keluarga dengan kesejahteran subjektif kategori tinggi. Sementara itu, terdapat 14,3 persen kesejahteraan subjektif keluarganya termasuk kategori rendah.

\section{Lingkungan Pengasuhan}

Hasil penelitian menunjukkan bahwa kualitas lingkungan pengasuhan untuk anak usia 0-36 bulan berada pada kategori rendah $(81,6 \%)$. $\mathrm{Hal}$ ini dikarenakan dari dimensi lingkungan pengasuhan ibu belum dapat melakukan pengasuhan yang optimal. Pada dimensi tanggap rasa dan kata, penerimaan perilaku anak, pengorganisasian lingkungan, dan penyediaan mainan anak masih terkategori rendah. Selanjutnya, pada dimensi yang lain seperti keterlibatan ibu dan kesempatan variasi asuhan berada pada kategori sedang. Adapun skor rata-rata kualitas lingkungan pengasuhan usia 0-36 bulan adalah 22,8, dengan skor minimal 11 dan skor maksimal 32.

Tabel 2 Sebaran keluarga berdasarkan kategori kesejahteraan objektif dan subjektif

\begin{tabular}{lcc}
\hline \multicolumn{1}{c}{ Kategori } & $\mathrm{n}$ & $\%$ \\
\hline Kesejahteraan Objektif & & \\
Sejahtera & 70 & 100,0 \\
Tidak sejahtera & 0 & 0 \\
\hline Total & 70 & 100.0 \\
\hline Kesejahteraan Subjektif & & \\
Rendah & 10 & 14,3 \\
Sedang & 54 & 77,1 \\
Tinggi & 6 & 8,6 \\
\hline Total & 70 & 100,0 \\
\hline
\end{tabular}


Tabel 3 Sebaran keluarga berdasarkan kategori komponen lingkungan pengasuhan (\%)

\begin{tabular}{lrrr}
\hline Subskala HOME & Rendah & Sedang & Tinggi \\
\hline Usia 0-36 bulan & & & \\
Sikap tanggap & 63,6 & 27,3 & 9,1 \\
Penerimaan & 78,8 & 18,2 & 0,0 \\
$\begin{array}{l}\text { Pengorganisasian } \\
\text { lingkungan anak }\end{array}$ & 54,5 & 45,5 & 0,0 \\
Ketersediaan media & 66,7 & 333 & 0,0 \\
pembelajaran & & & \\
Keterlibatan & 15,2 & 66,7 & 8,2 \\
Variasi stimulasi & 39,4 & 48,5 & 12,1 \\
\hline Total & 81,6 & 18,2 & 0,0 \\
\hline Usia 37-72 bulan & & & \\
Ketersediaan bahan & 10,8 & 89,2 & 0,0 \\
ajar & & & \\
Stimulasi Bahasa & 35,1 & 35,1 & 29,7 \\
Lingkungan fisik & 45,9 & 40,5 & 13,5 \\
Sikap tanggap & 40,5 & 35,1 & 24,3 \\
Stimulasi akademik & 40,5 & 16,2 & 43,2 \\
Modeling & 5,4 & 62,2 & 32,4 \\
Variasi stimulasi & 59,5 & 35,1 & 5,4 \\
Penerimaan & 70,3 & 21,6 & 8,1 \\
\hline Total & 48,6 & 51,4 & 0,0 \\
\hline & & & \\
\hline
\end{tabular}

Sementara itu, kualitas lingkungan pengasuhan pada anak kelompok usia 37-72 bulan, menunjukkan bahwa mayoritas ibu $(51,4 \%)$ termasuk ke dalam kategori sedang dan ditemukan 48,6 persen pengasuhannya dalam kategori rendah. Pada dimensi lingkungan fisik, kehangatan dan penerimaan, stimulasi akademik, variasi pengalaman dan penerimaan masih tergolong rendah. Selanjutnya pada dimensi stimulasi belajar dan modeling terkategori sedang (Tabel 3). Rata-rata skor kualitas lingkungan pengasuhan untuk anak usia 37-72 bulan adalah 35,4, dengan skor minimal 26 dan skor maksimal 45 .

Pengaruh Karakteristik Keluarga, Kualitas Pernikahan, dan Kesejahteraan Keluarga terhadap Lingkungan Pengasuhan

Hasil penelitian ini dengan analisis regresi linier model variabel-variabel yang berpengaruh terhadap lingkungan pengasuhan menunjukkan angka Adjusted $R$ Square sebesar 0,482, artinya model tersebut dapat menjelaskan 48,2 persen variabel-variabel yang memengaruhi lingkungan pengasuhan dan sisanya 51,8 persen dipengaruhi variabel lain di luar penelitian ini. Hasil penelitian juga menunjukkan bahwa lama menikah $(\beta=0,264$; $p=0,008)$, usia menikah istri $\quad(\beta=0,309$; $p=0,001)$, kualitas pernikahan $(\beta=0,240$; $p=0,021)$, dan kesejahteraan subjektif $(\beta=0,391$; $\mathrm{p}=0,001$ ) berpengaruh positif signifikan terhadap kualitas lingkungan pengasuhan.
Tabel 4 Pengaruh karakteristik keluarga, kualitas pernikahan, dan kesejahteraan keluarga terhadap lingkungan pengasuhan

\begin{tabular}{|c|c|c|c|}
\hline Variabel & $\mathrm{B}$ & $\beta$ & Sig. \\
\hline Konstanta & $-31,238$ & & 0,033 \\
\hline $\begin{array}{l}\text { Lama } \\
\text { Menikah }\end{array}$ & 0,512 & 0,264 & $0,008^{\star *}$ \\
\hline $\begin{array}{l}\text { Usia menikah } \\
\text { istri }\end{array}$ & 2,660 & 0,309 & $0,001^{\star *}$ \\
\hline $\begin{array}{l}\text { Lama } \\
\text { pendidikan } \\
\text { istri }\end{array}$ & 0,256 & 0,031 & 0,741 \\
\hline $\begin{array}{l}\text { Pendapatan } \\
\text { per kapita }\end{array}$ & $3,437 \times 10^{-6}$ & 0,116 & 0,299 \\
\hline $\begin{array}{l}\text { Kualitas } \\
\text { pernikahan }\end{array}$ & 0,172 & 0,240 & $0,021^{*}$ \\
\hline $\begin{array}{l}\text { Kesejahteraan } \\
\text { objektif }\end{array}$ & $-0,030$ & $-0,029$ & 0,789 \\
\hline $\begin{array}{l}\text { Kesejahteraan } \\
\text { subjektif }\end{array}$ & 0,400 & 0,391 & $0,001^{\star *}$ \\
\hline Uji F & & & 10,167 \\
\hline Sig & & & $0,000^{* *}$ \\
\hline R Square & & & 0,534 \\
\hline $\begin{array}{l}\text { Adjusted } R \\
\text { Square }\end{array}$ & & & 0,482 \\
\hline
\end{tabular}

Temuan tersebut menunjukkan bahwa setiap kenaikan satu satuan lama menikah pasangan suami istri maka akan menaikkan kualitas lingkungan pengasuhan sebesar 0,512 poin dan setiap kenaikan satu satuan usia menikah istri maka akan menaikkan kualitas lingkungan pengasuhan sebesar 2,660 poin. Selanjutnya setiap kenaikan satu satuan kualitas pernikahan keluarga maka akan menaikkan kualitas lingkungan pengasuhan sebesar 0,172 poin serta setiap kenaikan satu satuan kesejahteraan subjektif keluarga maka akan menaikkan kualitas lingkungan pengasuhan sebesar 0,400 poin. Hal ini berarti semakin rendah usia menikah istri, semakin rendah kualitas pernikahan, dan semakin rendah kesejahteraan subjektif maka semakin rendah pula kualitas lingkungan pengasuhan yang diberikan pada anak (Tabel 5).

\section{PEMBAHASAN}

Individu yang menikah di usia muda belum memiliki kesiapan untuk menikah sehingga rentan dengan perceraian atau perpisahan (Tsania, 2014). Sebagian besar suami dan istri memiliki pendidikan yang rendah yaitu jenjang SD. Menurut Fadlyana dan Larasaty (2009), pada keluarga yang mayoritas pendidikan pasangangannya adalah SD menunjukkan bahwa semakin rendah capaian pendidikan 
maka semakin muda usia menikah. Yadollahi et al. (2009) menyatakan bahwa tingkat pendidikan adalah salah satu determinan penting yang akan menentukan status ekonomi dan pekerjaan seseorang. Menurut Herawati (2012), tingkat pendidikan akan berimplikasi pada jenis pekerjaan yang dimiliki. Hasil penelitian menunjukkan sebagian besar istri memilih untuk menjadi ibu rumah tangga. Menurut Rizkillah (2014), istri yang tidak bekerja atau tidak mempunyai pekerjaan tetap cenderung memiliki usia menikah lebih awal.

Kebahagiaan bersifat subjektif dan berkaitan dengan kenikmatan yang dialami seseorang terhadap objek yang bisa dicapainya, seperti aspek personal, ekonomi, dan sosial. Sementara itu, kepuasaan berfokus pada kebutuhan batiniah yang memotivasi perilaku dengan cara-cara tertentu (Nurani, 2004). Hasil penelitian menemukan bahwa mayoritas istri menyatakan kualitas pernikahannya dalam kategori sedang. Pada dimensi kebahagiaan, capaian tertinggi aspek komitmen pernikahan istri menunjukkan mayoritas istri selalu menjaga komitmen pernikahan. Hal ini sesuai dengan penelitian terdahulu bahwa kebahagiaan tercapai dengan adanya komunikasi dan keterbukaan antara pasangan dan keluarga pasangan sehingga dapat menjaga komitmen pernikahan (Rizkillah, 2014; Nurani, 2004). Menurut Allendorf dan Ghimire (2012) pendidikan memiliki hubungan positif signifikan dengan komunikasi dan kebersamaan dengan pasangan.

Sementara itu, capaian terendah pada aspek ekonomi terlihat dari mayoritas istri yang menyatakan sering berdebat mengenai alokasi uang untuk membeli pakaian dan makanan, pendidikan anak, pengobatan keluarga, serta merawat rumah. Menurut Rahman dan Nasrin (2012) keadaan ekonomi merupakan salah satu yang menyebabkan terjadinya pernikahan muda. Hasil penelitian Higginbotham dan Felix (2009) menyatakan permasalahan ekonomi meningkatkan risiko permusuhan dan berkurangnya kehangatan emosional dalam pernikahan serta meningkatkan risiko konflik pernikahan dan tekanan pernikahan.

Berdasarkan dimensi kepuasan pernikahan, penelitian ini menemukan capaian tertinggi pada aspek cinta dan aspek hubungan intim ditunjukkan oleh hampir seluruh istri merasa puas dengan pasangan yang mencintai sampai saat ini. Menurut Lavner, Karney, dan Bradbury (2014); Allendorf dan Ghimire (2012); serta Nurani (2004) menyatakan kepuasan pernikahan dilandasi oleh rasa cinta atau ekspresi cinta pada pasangan dengan menunjukkan kasih sayang dari waktu ke waktu. Menurut Allendorf dan Ghimire (2012) pendidikan memiliki hubungan positif signifikan dengan kepuasaan pernikahan. Capaian terendah ditemukan pada aspek ekonomi, yang menunjukkan mayoritas istri tidak puas dengan masalah ekonomi. Keadaan tersebut menjadikan sumber konflik karena hanya ada satu sumber penghasilan keluarga. Penelitian Higginbotham dan Felix (2009) serta Kerkmann et al. (2000) menyatakan suami yang menikah di pedesaan merasa khawatir dengan keadaan keuangan dan istri merasa puas jika memiliki uang yang cukup untuk membeli kebutuhan.

Selanjutnya, pada aspek pengasuhan anak juga menunjukkan capaian terendah, yaitu setengah dari istri tidak puas dengan pembagian tanggung jawab membesarkan anak. Hal ini dikarenakan keterlibatan suami dalam mengasuh anak lebih sedikit dibandingkan ibu karena sebagian suami bekerja di luar kota. Hasil kajian Pathfinder International (2006) menyatakan bahwa seseorang yang menikah lebih muda akan berdampak terhadap ketidakstabilan dalam pernikahan, kesehatan menurun, kurang dapat menyelesaikan masalah dengan baik, angka partisipasi sekolah menurun, dan berakibat pada penurunan kesejahteraan anak. Menurut Allendorf dan Ghimire (2012) pasangan menikah muda masih tinggal bersama keluarga besar sehingga dalam mengasuh anak masih melibatkan keluarga besar pula.

Kualitas pernikahan merupakan suatu derajat pernikahan yang dapat memberi kebahagiaan dan kesejahteraan bagi pasangan suami istri sehingga dapat menjaga kelestarian pernikahan (Puspitawati, 2012). Menurut Tati (2004), kualitas pernikahan dipengaruhi faktorfaktor seperti jalinan cinta antara pasangan suami dan istri, saling mendukung, memenuhi kebutuhan fisik dan psikologis, mengelola ekonomi yang baik, dan menghindari terjadinya beda pendapat. Pertengkaran suami istri dapat menyebabkan kualitas pernikahan menurun (Newton dan Kiecolt-Glaser, 1995). Kualitas pernikahan berhubungan kuat dengan evaluasi kehidupan seseorang secara keseluruhan (Carr et al., 2014). Lima skala yang merefleksikan komponen kualitas pernikahan, yaitu ketidakstabilan pernikahan, interaksi pernikahan, jumlah dan kehebatan ketidaksetujuan, dan persepsi masalah dalam pernikahan. Penelitian terdahulu menemukan bahwa semakin lemah komunikasi dan emotional bonding suami istri maka semakin menurun kualitas perkawinan yang dirasakan 
pasangan (Puspitawati \& Setioningsih, 2011). Kebahagiaan dan kepuasan pernikahan didominasi oleh komunikasi yang baik dari masing-masing pasangan, serta kesepakatankesepakatan yang telah dibicarakan bersama (Wuryandari, Indrawati, \& Siswati, 2010), komunikasi yang terbuka dengan pasangan dan keluarga pasangan (Duvall dan Miller 1985).

Hasil penelitian ini menunjukkan tingkat kesejahteraan objektif pada ketegori sejahtera. Hal ini terjadi karena keluarga memiliki rumah sendiri dan keadaan fisik rumah yang cukup layak dengan menggunakan dinding tembok. Selain itu hampir seluruh keluarga menggunakan listrik sebagai alat penerangan. Fatimah dan Cahyono (2013) menyebutkan pasangan yang menikah usia muda keadaan ekonomi keluarganya belum aman sehingga kondisi rumah belum terawat dan rapi. Tingkat kesejahteraan subjektif keluarga juga dalam kategori sedang, atau istri sudah merasa cukup puas dengan kesejahteraan subjektifnya. Capaian tertinggi pada aspek dimensi sosial, yaitu istri merasa puas berhubungan dan berkomunikasi dengan orang tua. Capaian terendah adalah istri merasa kurang puas terhadap keuangan keluarga, kebutuhan makanan keluarga, kepemilikan aset, keterlibatan keluarga dalam kegiatan sosial, pendidikan anggota keluarga, penghasilan suami, dan belum tercapai tujuan keluarga.

Penelitian Turner dan Kaye (2006); Lever (2004) menyatakan kesejahteraan subjektif dalam kategori sedang, hal ini dipengaruhi oleh beberapa faktor diantaranya adalah hubungan dengan pasangan dan keikutsertaan kegiatan sosial, serta dampak dari interaksi dengan keluarga atau keluarga lain. Menurut Paul, Joseph, dan ljeoma (2013) pasangan menikah muda belum memiliki kesiapan psikologis sehingga tidak dapat mengembangkan interaksi dengan lingkungan sosial. Menurut Rahman dan Nasrin (2012) menikah muda berimplikasi terhadap kesejahteraan keluarga dan beresiko untuk wanita melahirkan serta kegiatan pengasuhan kurang optimal. Selanjutnya hasil penelitian Muflikhati (2010) faktor yang paling berpengaruh terhadap kesejahteraan keluarga adalah keadaan ekonomi keluarga (pendapatan, pengeluaran, dan aset keluarga).

Kualitas lingkungan pengasuhan usia 0-36 bulan berada dalam kategori rendah. Capaian terendah pada aspek tanggap rasa dan kata, aspek penerimaan perilaku, dan aspek penyediaan mainan. Namun ditemukan juga sebagian ibu dapat melakukan pengasuhan dengan optimal pada aspek kesempatan variasi asuhan. Kualitas lingkungan pengasuhan usia 37-72 bulan berada dalam kategori sedang. Capaian terendah pada aspek stimulasi belajar, aspek lingkungan fisik, aspek variasi pengalaman, dan aspek penerimaan. Ditemukan juga sebagian ibu dapat melakukan pengasuhan dengan optimal pada aspek stimulasi bahasa, aspek stimulasi akademik, dan aspek modeling. Kondisi ini disebabkan oleh faktor pengetahuan ibu dan pendidikan ibu juga yang kurang mengenai perkembangan anak. Hal ini sejalan dengan penelitian Latifah, Alfiasari, dan Hernawati (2009) kualitas pengasuhan di Kecamatan Ciampea berada dalam kategori sedang dan perkembangan anak dipengaruhi pengetahuan pengasuhan ibu yang masih rendah. Selain itu menurut Fadlyana dan Larasaty (2009) anak yang dilahirkan dari pasangan menikah muda beresiko mengalami keterlambatan perkembangan, kesulitan belajar, gangguan perilaku, dan cenderung menjadi orang tua pula di usia muda.

Karakteristik orang tua merupakan faktor yang dapat menentukan kualitas pengasuhan kepada anak (Hastuti, 2014). Penelitian Latifah, Alfiasari, dan Hernawati (2009) menyatakan faktor resiko yang memengaruhi pengasuhan dan perkembangan adalah pendidikan orang tua yang rendah, pendapatan keluarga yang rendah, pengetahuan tentang pengasuhan yang rendah, serta fasilitas dan sarana prasana yang masih kurang. Menurut Hasanah (2014) usia ibu yang belum cukup umur dan belum siap secara mental dan emosional, pengetahuan pengasuhannya belum memadai serta kurangnya kesadaran memberikan fasilitas belajar untuk menstimulasi anak juga merupakan factor resiko bagi orang tua dalam pengasuhan anak. Pendidikan merupakan faktor yang memengaruhi perempuan dalam melakukan pengasuhan, merawat, dan menjaga anak (Signh, Rai, \& Signh, 2012). Hasil penelitian Fadlyana dan Larasaty (2009) usia menikah yang masih muda dalam melaksanakan tugas sebagai orang tua disertai kurangnya keterampilan pengasuhan akan beresiko mengalami kesalahan pengasuhan. Maria (2013) yang menyatakan tingkat pendapatan per kapita berhubungan positif signifikan dengan lingkungan pengasuhan.

Penelitian ini menemukan bahwa lama menikah, usia menikah istri, kualitas pernikahan, dan kesejahteraan subjektif memiliki pengaruh positif signifikan terhadap kualitas lingkungan pengasuhan. Penelitian ini menunjukkan bahwa lama pernikahan yang 
lebih muda, usia menikah istri yang lebih muda, penurunan kualitas pernikahan istri, dan penurunan kesejahteraan subjektif maka akan menurunkan kualitas lingkungan pengasuhan anak. Hasil penelitian ini sedikit berbeda dengan penelitian Rizkillah (2014) yang menemukan lama menikah berpengaruh positif terhadap lingkungan pengasuhan. Pernikahan yang usianya lebih lama membuat ibu memiliki pengetahuan dan pengalaman yang banyak sehingga kualitas lingkungan pengasuhan anak yang diberikan dapat lebih baik.

Penelitian Dewanggi (2014) juga menyebutkan kualitas lingkungan pengasuhan anak dipengaruhi oleh usia ibu saat menikah. Ibu yang menikah dengan usia yang lebih matang akan memiliki pendidikan dan pengetahuan pengasuhan yang lebih baik sehingga dapat memberikan stimulasi perkembangan anak. Penelitian Rizkillah (2014) dan Sunarti et al. (2005) menyatakan kualitas pernikahan berpengaruh positif terhadap lingkungan pengasuhan. Menurut Nurani (2004), kualitas pernikahan diperoleh dari keharmonisan komunikasi suami dan istri sehingga tercapai suasana nyaman untuk mengoptimalkan pengasuhan yang diberikan kepada anak. Hasil penelitian tersebut menunjukkan kesesuaian dengan hasil penelitian ini yang juga menemukan bahwa lama pernikahan yang semakin lama menjadikan ibu mempunyai pengetahuan dan pengalaman sehingga kegiatan pengasuhan yang dilakukan lebih optimal. Usia ibu yang belum matang dan belum siap untuk menikah dapat memengaruhi kualitas pemberian stimulasi perkembangan anak. Hal ini dikarenakan kurangnya pendidikan, pengetahuan, pengalaman yang diperoleh oleh ibu. Selain itu, hubungan dengan suami yang kurang harmonis akibat usia yang masih muda akan menyebabkan ibu kurang optimal dalam melakukan pengasuhan.

Penelitian Aber, Bennet, dan Lii (1997) menunjukkan bahwa kualitas lingkungan pengasuhan juga dipengaruhi oleh kesejahteraan subjektif. Menurut Ariati (2010) kesejahteraan subjektif adalah persepsi seseorang terhadap pengalaman hidupnya dan kondisi yang dialami. Apabila tidak dapat menyesuaikan diri dengan kondisi kehidupan maka seseorang dapat mengalami stres. Menurut Aber Bennet, dan Lii (1997) kondisi stres dan tertekan dari orang tua terutama ibu, akan cenderung melakukan pengasuhan yang negatif kepada anak seperti: memukul anak, berteriak, dan menampar anak. Kondisi ini juga dapat meningkatkan konflik pernikahan. Hasil penelitian tersebut sesuai dengan penelitian ini.
Kesejahteraan subjektif merupakan persepsi kepuasan dengan kondisi yang ada saat ini, apabila ibu tidak dapat menerima dan beradaptasi dengan kondisi sekarang berarti ibu tidak puas. Jika ibu tidak puas dengan kondisi saat ini ibu akan merasa lebih tertekan dan stres sehingga dapat menyebabkan kurang optimalnya pengasuhan yang diberikan ibu. Selain itu, kondisi ini dapat memicu konflik dengan pasangan.

\section{SIMPULAN DAN SARAN}

Penelitian ini melibatkan pasangan yang menikah di usia muda dengan rata-rata usia menikah istri yaitu 17 tahun dan rata-rata usia menikah suami adalah 22 tahun. Pendidikan rata-rata dari pasangan suami dan istri adalah tamat SMP. Mayoritas keluarga termasuk dalam kategori keluarga kecil dengan rata-rata pendapatan per kapita per bulan sebesar Rp594.696.

Kualitas pernikahan pada dimensi kebahagiaan memiliki capaian yang tinggi pada aspek komitmen pernikahan dan terendah pada aspek ekonomi. Dimensi kepuasan pernikahan menunjukkan capaian tertinggi pada aspek cinta dan hubungan intim serta aspek terendah pada aspek ekonomi dan aspek pengasuhan anak. Kesejahteraan objektif keluarga pada kategori sejahtera dikarenakan memiliki rumah sendiri dan kondisi fisik rumah baik. Kesejahteraan subjektif berdasarkan persepsi istri pada kategori sedang dengan capaian paling tinggi aspek hubungan dengan pasangan dan capaian terendah, yaitu istri merasa kurang puas terhadap keuangan keluarga, kebutuhan makanan keluarga, kepemilikan aset, keterlibatan keluarga dalam kegiatan sosial, pendidikan anggota keluarga, penghasilan suami, dan belum tercapai tujuan keluarga.

Kualitas lingkungan pengasuhan anak umur 036 bulan pada kategori rendah. Kualitas lingkungan pengasuhan anak umur 37-72 bulan pada kategori sedang. Hasil penelitian menunjukkan bahwa kualitas pernikahan, kesejahteran objektif, dan kesejahteraan subjektif berhubungan positif sangat signifikan dengan lingkungan pengasuhan. Faktor yang berpengaruh signifikan positif terhadap kualitas lingkungan pengasuhan adalah lama menikah, usia menikah istri, kualitas pernikahan, dan kesejahteraan subjektif.

Berdasarkan hasil yang diperoleh dari penelitian ini, diharapkan pelaksanaan kebijakan pemerintah seharusnya lebih tegas 
dan efektif terhadap program pendewasaan usia menikah perempuan untuk mengoptimalkan lingkungan pengasuhan anak. Sementara itu kolaborasi dari beragam pemangku kepentingan seperti LSM dan perguruan tinggi sangat diperlukan dalam memberikan penyuluhan secara rutin dan menyeluruh tentang cara pengasuhan anak khususnya pada keluarga dengan pasangan menikah di usia muda. Selain itu, diharapkan keluarga besar memberikan dukungan berupa materi juga diperlukan untuk mengoptimalkan tumbuh kembang anak.

\section{DAFTAR PUSTAKA}

Ahmed, S., Khan, S., Alia, M., \& Noushad, S. (2013). Psychological impact evaluation of early marriages. International Journal of Endorsing health Science Research, 1(2), 84-86.

[BKKBN] Badan Koordinasi Keluarga Berencana Nasional. (2012). Pernikahan dini pada beberapa provinsi di Indonesia: dampak overpopulation, akar masalah dan peran kelembagaan di daerah. Jakarta (ID): BKKBN

[BPS] Badan Pusat Statistik. (2000). Statistik kesejahteraan rakyat. Jakarta, ID: BPS.

Aber, L., Bennet, N. G., \& Lii J. (1997). The effect of poverty on child health and development. Rev Public Health, 18, 46383.

Allendorf, K., \& Ghimire, D. (2012). Determinants of marital quality in an arranged marriage society. Research Reports. University of Michigan (USA).

Ariati, J. (2010). Subjektif well- being (kesejahteraan subjektif) dan kepuasan kerja pada staf pengajar (dosen) di lingkungan fakultas psikologi Universitas Diponegoro. Jurnal Psikologi Undip, 8(2), 117-123. https://doi.org/10.14710/jpu.8.2.117-123.

Carr, D., Freedman, V. A., Cornman, J. C., \& Schwarz, N. (2014). Happy marriage, happy life? Marital quality and subjective well-being in later life. Journal of Marriage and Family, 76, 930-948. doi: 10.1111/jomf.12133

Conger, R. D., Conger, K. J., \& Martin, M. J. (2010). Socioeconomic status, family processes, and indivisual development. Journal of Marriage and Family, 72, 685704, doi: 10.1111/j.17413737.2010.00725.x
Dewanggi, M. (2014). Pengaruh kelekatan, gaya pengasuhan, kualitas lingkungan pengasuhan terhadap karakter anak perdesaan dan perkotaan (Tesis). Institut Pertanian Bogor, Bogor, Indonesia.

Duvall, E. M., \& Miller B. C. (1985). Marriage and family development. New York: Harper\&Row Publisher.Inc.

Fadlyana, E., \& Larasaty, S. (2009). Pernikahan usia dini dan permasalahannya. Sari Pediatri, 11(2), 136-140.

Fatimah, D., \& Cahyono, R. (2013). Pemenuhan aspek-aspek kepuasan perkawinan pada remaja perempuan yang mengalami kehamilah pranikah. Jurnal Psikologi Pendidikan dan Perkembangan, 2(1), 1-7.

Hasanah, T. (2014). Pengaruh pemberdayaan keluarga terhadap peningkatan pengetahuan perkembangan dan pengasuhan anak usia prasekolah (Tesis). Institut Pertanian Bogor, Bogor, Indonesia.

Hastuti, D. (2014). Pengasuhan: teori dan prisip serta aplikasinya di Indonesia. Bogor, ID: IPB Press.

Herawati, T. (2012). Manajemen sumberdaya keluarga dan ketahanan keluarga peserta program pemberdayaan masyarakat di pedesaan (kasus di Kabupaten Bogor) (Disertasi). Institut Pertanian Bogor, Bogor, Indonesia.

Helliwell, J. F., \& Putnam, R. D. (2004). The social context of well being. The Phil. Trans. R. Soc. Lond. B, 359, 1435-1446

Higginbotham, B. J., \& Felix, D. (2009). Economic predictors of marital quality among newly remarried rural and urban couples. Family Science Review, 14(2), 18-30.

Kerkmann, B. C., Lee, T.R., Lown, J. M., \& Allgood, S. M. (2000). Financial management, financial problems and marital satisfaction among recently married university student. Financial Counseling and Planning, 11(2), 55-65.

Kersh, J., Hedvat, T. T., Hauser-Cram, P., \& Warfleld, M. E. (2006). The contribution of marital quality to the well-being of parents of children with developmental disabilities. Journal of Intellectual Disability Research, 50(12), 883-893.

Lai, C. S. (2011). Parental marital quality and family environment as predictor of delinquency amongst selected secondary 
school students in Malaysia. British Journal of Arts and Social Sciences, 2(2), 102-121.

Latifah, M., Alfiasari, \& Hernawati, N. (2009). Kualitas tumbuh kembang, pengasuhan orang tua dan faktor resiko komunitas pada anak prasekolah wilayah pedesaan di Bogor. Jurnal IImu Keluarga dan Konsumen, 2(2), 143-153. http://dx.doi.org/10.24156/jikk.2009.2.2.1 43.

Lavner, J. A., Karney, B. R., \& Bradbury, T. N. (2014). Relationship problems over the early years of marriage: stability or change?. Journal of Family Psychology, 28(6), 979-985. doi: 10.1037/a0037752.

Lever, J. A. (2004). Poverty and subjective wellbeing in Mexico. Journal of Social Indicators Research, 68, 1-34.

Maria, H. (2013). Kecerdasan spiritual ibu kualitas pengasuhan dan kreativitas anak sekolah dasar progresif dan non progresif di Kota Bogor (Tesis). Institut Pertanian Bogor, Bogor, Indonesia.

Muflikhati, I. (2010). Analisis dan pengembangan model peningkatan kualitas sumber daya menusia dan kesejahteraan keluarga di wilayah pesisir Provinsi Jawa Barat (Disertasi). Institut Pertanian Bogor, Bogor, Indonesia.

Newton, T. L., \& Kiecolt-Glaser, J. K. (1995). Hostility and erosion of marital quality during early marriage. J. Behave Med., 18(6), 601-619.

Nurani, A. S. (2004). Pengaruh kualitas perkawinan, pengasuhan anak dan kecerdasan emosional terhadap prestasi belajar anak (Tesis). Institut Pertanian Bogor, Bogor, Indonesia.

[Pathfinder International]. (2006). Report on Cause and consequences of early marriage in Amhara Region. Ethiopia: Pathfinder International.

Paul, N., Joseph, U. O., ljeoma, O. C. (2013). Education an antidote against early marriage for the girl-child. Journal of Educational and Social Research, 3(5), 73-78.

Puspitawati, H., \& Setioningsih, S. S. (2011). Fungsi pengasuhan dan interaksi dalam keluarga terhadap kualitas perkawinan dan kondisi anak pada keluarga tenaga kerja wanita (TKW). Jurnal IImu Keluarga dan Konsumen, 4(1), 11-20.
Puspitawati H. (2012). Gender dan keluarga. Bogor, ID: IPB Press.

Puspitawati, H., \& Setioningsih, S. S. (2011). Fungsi pengasuhan dan interaksi dalam keluarga terhadap kualitas perkawinan dan kondisi anak pada keluarga Tenaga Keja Wanita (TKW). Jurnal IImu Keluaga dan Konsumen, 4(1), 11-20.

Rahman, M. M., \& Nasrin, S. O. (2012). Factors affecting early marriage and early conception of women: a case of slum areas in Rajshahi City, Bangladesh. Journal of Sociology and Antropology, 4(2), 54-62.

Rizkillah, R. (2014). Kualitas pernikahan dan lingkungan pengasuhan pada keluarga dengan suami istri bekerja (Tesis). Institut Pertanian Bogor, Bogor, Indonesia.

Rizkillah R., Sunarti, E., Herawati T. (2015). Kualitas perkawinan dan lingkungan pengasuhan pada keluarga dengan suami istri bekerja. Jurnal IImu Keluaga dan Konsumen, 8(1), 10-19.

Schramm, D. G. (2007). Economic hardship, stressors, and marital quality among stepcouples: an examination of direct and indirect effect (Disseratation). Auburn University, Alabama, Amerika Serikat.

Shabir, S. \& Nisar, S. R. (2015). Depression, axienty, stress, and life satisfaction among early and late married females. European Journal of Business and Social Sciences, 4(08), 128-131.

Singh, L., Rai, R. K., \& Singh, P. K. (2012). Assessing the utilization of maternal and child health care: among married adolescent women: evidence from India. Journal Biosoc. Sci, 44, 1-26.

Iskandar, A., Hartoyo, Khomsan, A., \& Sumarwan, U. (2007). Analisis praktek manajemen sumberdaya keluarga dan dampaknya terhadap kesejahateraan keluarga di Kabupaten dan Kota Bogor (Disertasi). Institut Pertanian Bogor, Bogor, Indonesia.

Sunarti, E., Tati, Atat, S., Noorhaisma, R., \& Lembayung D. P. (2005). Pengaruh tekanan ekonomi, dukungan sosial, kualitas pernikahan, pengasuhan, dan kecerdasaran emosi anak terhadap prestasi belajar anak. Media Gizi \& Keluarga, 29(1), 34-40.

Tati. (2004). Pengaruh tekanan ekonomi keluarga, dukungan sosial dan kualitas pernikahan terhadap pengasuhan anak 
(Tesis). Institut Pertanian Bogor, Bogor, Indonesia.

Tsania, N. (2014). Karakteristik keluarga, kesiapan menikah istri dan perkembangan anak usia 3-5 tahun (Tesis). Institut Pertanian Bogor, Bogor, Indonesia.

Turner, M. A., \& Kaye, D. R. (2006). How does family well-being vary across different types of neighborhoods?. Paper The Urban Institute, 6, 1-44.
[WHO]. (2006). Married Adolencents: No Place of Safety. Geneva, Switzerland $(\mathrm{CH})$ : WHO Press.

Wuryandari, M., Indrawati, E. S., \& Siswati. (2010). Perbedaan persepsi suami istri terhadap kualitas pernikahan antara yang menikah dengan pacaran dan ta'aruf. Jurnal Psikologi, 4(2), 1-8.

Yadollahi M., Paim L., Othman M., Suandi T. (2009). Factors affecting family status. European Journal of Scientific Research, 37(1), 94-109. 